\title{
THE ENHANCEMENT OF CONSISTENCY OF INTERPRETATION SKILLS ON THE NEWTON'S LAWS CONCEPT
}

\author{
Yudi Kurniawan ${ }^{1)}$ \\ 1) STKIP Singkawang, Singkawang, Indonesia \\ E-mail: yudikurniawan1012@gmail.com
}

\begin{abstract}
Conceptual understanding is the most important thing that students should have rather than they had reaches achievement. The interpretation skill is one of conceptual understanding aspects. The aim of this paper is to know the consistency of students' interpreting skills and all at once to get the levels of increasing of students' interpretations skill. These variables learned by Interactive Lecture Demonstrations (ILD) common sense. The method of this research is pre-experimental research with one group pretestposttest design. The sample has taken by cluster random sampling. The result had shown that $16 \%$ of all student that are have perfect consistency of interpretation skill and there are increasing of interpretation skill on $84 \%$ from unknown to be understand (this skill). This finding could be used by the future researcher to study in the other areas of conceptual understanding aspects.
\end{abstract}

Keywords: Consistency; Interpretation Skill; Newton's Laws

\section{INTRODUCTION}

Physics is a kind of the way to observe a phenomenon either directly or through experiment. The conceptual understanding process in physics learning is more important than achievement in result. Understanding must be obtained through the learning process because students have knowledge before get the new information in the classroom. The learning process in physics have designed to assist all of student, to assist students' difficulties to understand the concept while they were studying in the class [1] [2].

In an effort to more understand the knowledge that derived from initial ideas before learning and learning experiences, that should it has an approach or method that provides every contextual problem. In the end, its benefits to engage students in responsible for their own learning and more questions than to accept a spontaneous statement. Therefore, students who are considered to have good conceptual understanding are the ability to explain many natural phenomena and arrange them in common terms, in different context [3] [4].

This statement became a basics argument that the consistency in the scientific concept is very important. Students has able to re-write their understanding to another form/ sentence in the same define, as like as scientific conception. If they are able to pass this phase, they are would get deep conceptual understanding [5] [6].

To facilitate an excellence understanding in their class, a teacher at various levels of education should be able to apply the learning process with student-centered approach. Student- centered learning can provide to students with "natural" experience in physics learning and can improve students' conceptual understanding [6] [7]. Therefore, it impossible to enhance student's cognitive level without applying an innovative teaching method or learning models.

There is one of various innovative learning models that it can support the conceptual understanding and it called as Interactive Lecture Demonstrations (ILD). The adaptation of ILD versions of Sokoloff and Thornton is a common sense oriented ILD (CS) based on everyday experience. This model able to overview of scientific concepts either directly and virtually so that learned concepts can be demonstrated and student could observe it. The virtual concept (ex. in this study: Newtons $1^{\text {st }}$ Laws) most of them became easier to understand after they saw the video or virtual simulation [8]. Demonstrations in ILD can generate student motivation to be more active in observing the phenomena associated with solving daily individual problems [9].

In this study, the concept that tested are Newton's Law. This is because Newton's Laws concept are basics concepts in physics learning at the elementary, secondary schools or college level. The Newton Law always related to force and motion and as we know, those concepts are taught in the all levels of education [10] [11] [12].

Based on the background, this research is going to get data of the consistency of interpretation skill in Newton Laws concept through implementation of ILD common sense oriented. Its imply to get description the number of student that enhance their interpretation skill after treatment. 


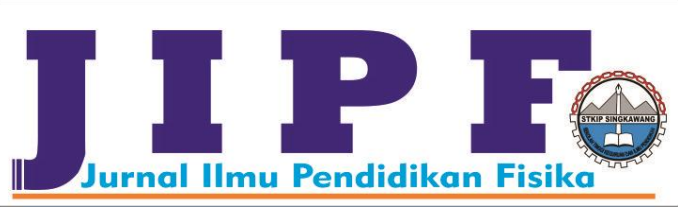

\section{METHODS}

This research is quantitative research. This type of research is pre-experimental design because it does not use control class. The research design is one group pretest and posttest design. The population in this study is all students of class IX in one of state junior high school Pandeglang District, Banten Province.

The sample in this study was chosen by cluster random sampling technique that it considering to represent the population. Total of students that involved in this research are 32 students.

Data collection techniques used are interpretation skill test (IST) that in the multiple-choice form. This test was given to student before and after treatment which on each item of IST, student had answered the test four times.

Results of student answers are processed and scored, then calculated by "just right" method so IST analyze by correct student answers only. As anticipate the data collection, the ngain criteria used to facilitate the increasing of student's interpretation skills. The category of this gain as the following on Table 1.

TABLE 1

N-GAIN CRITERIA

\begin{tabular}{cc}
\hline Persentase & Criteria \\
\hline $0,00<\mathrm{g} \leq 0,30$ & Low \\
\hline $0,30<\mathrm{g} \leq 0,70$ & Medium \\
\hline $0,70<\mathrm{g} \leq 1,00$ & High \\
\hline
\end{tabular}

\section{RESULT AND DISCUSSION}

In this study, students' skill in interpreting a data, interpreting a phenomenon tested and trained in a demonstration process to prove a prediction prior treatment. Students would explored the phenomenon and wrote it on the Prediction Sheet.

In the implementation of the demonstration, students are faced with phenomena conducted in front of the class. While the demonstration process, students' skill was tested. Skills in interpreting, translating, making the same phenomenon but with other forms, and changing the appearance of the phenomenon in the form of visual display (from the process of science with the senses) into a writing in the form of statements or laws physics.

These results (the prediction sheet analyses) are used to support the results of calculation of pre and post of IST. The consistency of the students in providing answers to each item indicates that students have excellent interpretation skills.

There are only five students with percentage are $16 \%$ (students' code 7, 8, 9, 11, and 27) that very consistent to complete IST correctly, in other word they have solid interpretation skills. But it doesn't mean that the other failed to pass the IST. Most of students change positively from unknown the concept to understand the concept. And the highest increasing in the change in percentage $75 \%$. Some of
Jurnal Ilmu Pendidikan Fisika

Volume 3 Number 1 month March 2018. Page 28-30 p-ISSN: 2477-5959 e-ISSN: 2477-8451

the increasing of interpretation skill of student as list as on Table 2.

TABLE 2

RECAPITULATION OF INTERPRETATION SKILL

\begin{tabular}{rc}
\hline Student's Code & Criteria \\
\hline $3,10,14,20,23,28,30,32$. & Low
\end{tabular}

$1,2,4,5,6,12,13,15,16,17,18,19,21,22,24$, Medium $26,29,31$.

25

Based on the Table 2, almost all student had positive change to be understand the concept, and the most of them reach the medium criteria.

The less improvement of interpretation skill on the high criteria, could be seen by some factors. The first, there are change of teaching/ learning method from informative to new teaching method (ILD common sense). It could affect to make students hard to find all of information presented in the demonstration session.

The changing of teaching method also effects to teacher's preparation before they start their class. Teacher's skill in the design of experiment, asking skill, manage class to build the interactive class, and teacher' patience could be affect to learning process in their class [14]

Most of student failed to identify the variable by observing the phenomena (demonstration). The other factor is students self-willingness to write all of information to the sheet. It imply, if student wrote step by step of demonstrations, it should be support the students' interpretation skill better than this result. And the last in this study, the low criteria in the increasing of intepretations skill (exclude of five student had consistent), this skill only train on the beginning process of observing.

\section{CONCLUSION}

Based on the data analysis, could be conclude that only five student $(16 \%)$ had perfect consistence of interpretation skill in the Newton Law concept. Most of them had changed positively from unknown the concept to the understand the concept. It higly reccommended for next researcher to explore another skill deeply and to the other concepts.

\section{REFERENCES}

[1] Simamora, R., Sinaga, P., \& Jauhari, A. (2016). Pembelajaran Fisika Menggunakan Multirepresentasi Untuk Meningkatkan Kemampuan Kognitif Dan Kemampuan Pemecahan Masalah Siswa SMP Pokok. Prosiding SNIPS 2016, pp. 501-505.

[2] Nadiya, Rosdianto, H., \& Murdani, E. (2016). Penerapan Model Pembelajaran Group Investigation (GI) untuk Meningkatkan Keterampilan Berpikir Kritis Siswa pada Materi Gerak Lurus Kelas X. JIPF (Jurnal Ilmu Pendidikan Fisika), 1(2), 49-51.

[3] Chase, C C., Shemwell, J.T., \& Schwartz, D.L. (2010). Explaining across contrasting cases for deep 
understanding in science: An example using interactive simulations. Proceeding ICLS '10 Proceedings of the 9th International Conference of the Learning Sciences, 1(2000): 153-160.

[4] Lisma, Kurniawan, Y., \& Sulistri, E. (2017). Penerapan Model Learning Cycle (LC) 7E Sebagai Upaya Peningkatan Pemahaman Konsep Aspek Menafsirkan dan Menyimpulkan Materi Kalor Kelas X SMA. JIPF (Jurnal Ilmu Pendidikan Fisika), 2(2), 35-37.

[5] Aminudin, D., Sutiadi, A., \& Samsudin, A. (2013). Ilmiah Siswa SMP Pada Konsep Gerak. WePFi Pendidik. Fis., 1(3): 1-8.

[6] Rosdianto, H., Murdani, E., \& Hendra (2017). The Implementation of POE (Predict Observe Explain) Model To Improve Student's Concept Understanding On Newton's Law. Jurnal Pendidikan Fisika, 6(1), 55-57.

[7] Tebabal, A., \& Kahssay, G. (2011). The Effects of Student-Centered Approach in Improving Students' Graphical Interpretation Skills and Conceptual Understanding of Kinematical Motion. Lat. Am. J. Phys. Educ., 5(2): 374-381.

[8] Ashkenazi, G., \& Weaver, G.C. (2007). Research and practice. Chem. Educ. Res. Pract., 8(2): 186-196.

[9] Checkley, D. (2010). High School Students' Perceptions of Physics, pp.1-228.

[10] Narjaikaew, P. (2013). Alternative Conceptions of Primary School Teachers of Science about Force and Motion. Procedia - Social and Behavioral Sciences, vol. 88: 250-257.

[11] Rosdianto, H. (2017). Pengaruh Model Generative Learning Terhadap Hasil Belajar Ranah Kognitif Siswa Pada Materi Hukum Newton. Jurnal Pendidikan Fisika dan Keilmuan (JPFK), 3(2), 66-69.

[12] Sulistri, E., \& Lisdawati. (2017). Using Three-Tier Test to Identify the Quantity of Student that Having Misconception on Newton's Laws of Motion Concept. JIPF (Jurnal Ilmu Pendidikan Fisika), 2(1), 4-6.

[13] Hake, R.R. (1999). Analyzing Change/ Gain Scores. America Education Research Association's DivisionD.Unpublished.Available http://www.physics.indiana.edu/ sdi/AnalyzingChangeGain.pdf

[14] Albert, O.O., Osman, A., \& Yungungu, A. (2014). An investigation of Factors that Influence Performance in KCSE Biology in selected secondary schools in Nyakach District, Kisumu County , Kenya The problem of poor performance in science subjects is global as indicated by studies done by Valverde and Sch. J. Educ. Hum. Dev., 3(2): 957-977. 